\title{
Capitalism, the Book of Amos and Adam Smith: An analysis of corruption
}

Author:
Mark Rathbone ${ }^{1}$
Affiliation
'Faculty of Economic and
Management Sciences,
North-West University,
Potchefstroom, South Africa
Corresponding author:
Mark Rathbone,
mark.rathbone@nwu.ac.za
Dates:
Received: 11 June 2020
Accepted: 04 Aug. 2020
Published: 30 Sept. 2020
code with your phone or
How to cite this article:
Rathbone, M., 2020,
'Capitalism, the Book of
Amos and Adam Smith:
An analysis of corruption',
HTS Teologiese Studies/
Theological Studies 76(4),
a6194. https://doi.
org/10.4102/hts.v76i4.6194
Copyright:
(C) 2020. The Authors.
Licensee: AOSIS. This work
is licensed under the
Creative Commons
Attribution License.

The purpose of this study is to challenge the criticism of capitalism by biblical scholars that is based on references to the prophetic tradition in the Old Testament and specifically the Book of Amos. In many of these reflections, capitalism is viewed as a corrupt and morally dysfunctional system that perpetuates economic injustice. In order to challenge these perspectives, the prophet Amos and Adam Smith (to whom the legacy of capitalism is generally traced) will be compared in terms of their understanding of corruption as an economic phenomenon and pressing problem in South Africa. This will be done to argue that both Amos and Smith, although from two distinct theoretical and historical perspectives, use similar analytic criteria to study corruption. Smith and Amos followed a dual view of corruption in which convictional decline took place. For Amos, the convictional dimension was represented specifically by a decline in belief in God and for Smith, by a decline in the values of the Enlightenment, such as liberty and equality; and at the same time, the moral dimension was represented by moral failure in terms of non-compliance with the law (תָרָ, tôrâh) of God (Amos 2:4) and corrupt practices by citizen and government officials (Smith). Amos notes that there is a theological deficit at the root of economic injustice

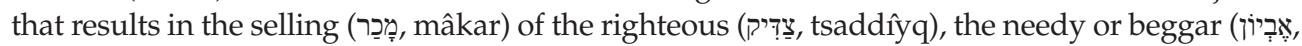
'ebyôn) and the dependent or weak (ל̦, dal) for private gain (Am 4:6). Law in the context of Amos is not only viewed as a moral imperative but the foundational principle of the structure of society (like liberty and freedom was for Smith). Therefore, a general criticism of capitalism based on moral failure and lack of conviction from Amos cannot be convincingly argued because Smith uses the same criteria. Criticism of capitalism should be more precise in terms of the loss of conviction and moral failures that Smith highlighted.

Contribution: The comparative analysis of corruption in the Book of Amos and the philosophy of Adam Smith highlights that both use similar criteria, namely: conviction and morality. Therefore, a more nuanced critique of Capitalism is by biblical scholars is crucial for meaningful dialogue between biblical scholarship and economics.

Keywords: Adam Smith; prophetic tradition; Book of Amos; corruption; morality; conviction; accountability.

\section{Introduction}

The purpose of this study is to challenge the criticism of capitalism by biblical scholars that is based on references to the prophetic tradition in the Old Testament and specifically the Book of Amos. In many of these interpretations of Amos, capitalism is viewed as a corrupt and morally dysfunctional system that perpetuates economic injustice. Many reflections on the prophetic tradition, and the Book of Amos specifically, draw the line between the prophetic tradition and the criticism of capitalism by focusing on the role of self-interest as an expression of greed and narcissism. Selfinterest and the egoism of this instinct are usually traced back to Adam Smith, who is viewed as the root cause of the injustices associated with contemporary capitalism (Carroll R 2002; Friedman \& Adler 2011; Haymond 2016 ; Mott \& Sider 2000; Saviour 2012; Umeanolue 2018).

In order to challenge these perspectives, the prophet Amos and Adam Smith will be compared in terms of their understanding of corruption as an economic phenomenon. This will be done to argue that both Amos and Smith, although from two distinct theoretical and historical perspectives, use similar analytic criteria to study corruption that can be useful to understand this phenomenon in the South African context. Smith and Amos followed a dual view of corruption in which convictional decline took place. For Amos, the convictional dimension was represented specifically by a decline in belief in God and for Smith, by a decline in the values of the Enlightenment, such as liberty and equality; at the same time, the moral dimension was represented by moral failure in terms of non-compliance with the law (תֶָ, tôrâh) of God (Amos) and corrupt practices by citizen and government officers (Smith). This comparison will specifically focus on the Book of Amos and references to corruption in The Theory of Moral 
Sentiments (TMS) ([1759] 2005) and An Inquiry into the Nature and Causes of the Wealth of Nations (WN) ([1776] 2007) in the light of contemporary research on Smith. This research will underline that Smith is not only being dealt a bad hand by generalised perceptions on his work but is incorrectly blamed for the injustices associated with contemporary capitalism (Rathbone 2015, 2018, 2019a).

In this article firstly, the phenomenon of corruption will be discussed from a global and South African perspective.

Secondly, references to corruption in the work of Adam Smith will be analysed in terms of the corruption of moral sentiments, taxation, the Poor Laws and the church, and the legal system, highlighting the role of conviction and morals in Smith's assessment of corruption. This is followed by analysis of the Book of Amos and a close reading of Amos 2:4-8 that will also clearly show that conviction and morals were integral to Amos's analysis of Israelite and Judean societies. In the final section, the implications of these criteria for addressing corruption will be discussed. It will be accentuated that a more nuanced critique of corruption and capitalism with reference to the Bible is crucial for understanding the root causes and possible solutions. Further, a more nuanced critique may also create a creative space for authentic dialogue between theology and economics that can lead to a more encompassing and interdisciplinary approach to analysis and problem-solving.

\section{Corruption}

The etymology ${ }^{1}$ of 'corruption' can be traced to the Latin word corruptus, which is the past participle of corrumpere [to destroy, spoil]. This past participle probably stems from rumpere [to break].

From the late 14th century, 'corruption' meant 'guilty of dishonesty involving bribery'. The etymology suggests that corruption involves moral deficiency, dishonest enrichment and the power to solicit others for personal gain, having a negative impact on structures (e.g. society and institutions). The problem of corruption is that it erodes the moral fabric of society, which results in a culture of corruption. The reason for this is that corruption causes a breakdown in trust in the systems and institutions of society (Venter \& De Regnaucourt 2010).

Once trust is broken, the failure of law and order is inevitable, and corruption becomes a pervasive culture. A further consequence is that democracy is threatened because public officers elected to serve citizens fail to deliver. Ultimately, corruption can destroy the economy and accelerate underdevelopment and poverty. This is particularly clear in developing economies in Africa.

The economic impact of corruption is further exacerbated by negative investor perceptions of the economy of a particular nation. The Corruption Perception Index (CPI), ${ }^{2}$ which

1.Viewed 05 December 2018, from www.etymonline.com/word/corrupt.

2.Viewed 05 December 2018, from www.tranparency.org/research/cpi. measures perceptions regarding corruption, ranked South Africa at 71st of 180 countries, with a count of 43 out of 100 in 2017. The most corrupt country was Somalia and the least New Zealand (score of 89). The important implication of these CPI scores is that a direct link can be drawn between foreign investment in an economy and corruption, or at least the lack of investment, as is the case of South Africa. The reason is that the higher the score of a country, the larger percentage of the investment actually goes towards the actual business invested in. In other words, the discount rate for investment is less. Alternatively, the opposite is also true. Because the larger part of the capital is used to secure contracts by paying bribes, investments in countries with a low CPI score are therefore less desirable.

A further negative economic influence of corruption is the fact that it increases underdevelopment because corrupt activities are directly linked to capital wastage (Lewis 2011). Infrastructure construction is crucial for development and economic growth in a society. However, corruption may entail that things like civil engineering infrastructure projects to build roads, bridges, dams and so forth are not constructed according to accepted engineering standards, with capital not being directed to the project but rather ending up in the hands of corrupt officials; for example, less than adequate raw materials are used, making the infrastructure vulnerable. This decreases the quality of the infrastructure to levels much lower than is acceptable and/or safe for use. The implication is that decay and even the destruction of the structures occur rapidly and may cause loss of life, with further negative implications for society. Finally, new capital must be invested in the same project within a short period of time. This doubles or in many case quadruples the cost of the same project.

The negative economic effect of corruption is directly reflected in the finances of the government of South Africa. It is estimated that corruption costs South Africa R27 billion annually, with the loss of about 66000 jobs (Shuma 2018). This is exacerbated by state capture as a special form of corruption, in which case individuals loot state-owned enterprises and illegally obtain state contracts, amongst others. Hofstater (2018), notes that this form of corruption cost South Africa at least R100bn. The scope and depth of corruption is one of the main aspects that contribute to low Gross Domestic Product growth in South Africa, acute unemployment and poverty.

It also highlights that corruption is also not only about poor personal morality; rather, it is a systemic problem that requires in-depth analysis and encompassing solutions to develop sustainable societal structures and strengthen democracy. Corruption has become an economic problem that with continued high unemployment and inequality may destabilise society and democracy for generations to come.

In the following section, Adam Smith's view of corruption will be discussed in terms of the analytic aspects of faith or belief and morality. 


\section{Adam Smith and corruption}

Hill (2006:636) notes that corruption had a much broader meaning until the start of the 19th century that focused less on individual morality than the corporeal moral health of the 'body politic'. This focus on the collective, influenced mainly by societal institutions like the state, focused on injustice related to the distribution of wealth, hierarchical power relations and corrupt leadership that resulted from 'bloated empire' (Hill 2006:637). Hill (2006) states that a 'bloated empire' can be identified by the following traits:

[A]ggressive militaristic expansion, ethnic hubris, irreligiousness, hedonism, systemic inequalities of wealth, civic withdrawal, overreliance on mercernary armies, distance between leaders and citizenry, and consequent loss of political virtue in both. (p. 637)

The premodern view of corruption focusses more on the system. In other words, the system becomes weak because the core values and belief in the importance of these values decline, and therefore the system is compromised (Wallis 2004).

Hill (2006:639) argues that Smith was more associated with a classical and broader view of corruption that was critical of the abuses caused by state structures that challenged the liberty of citizens. According to Hill (2006:639), this was done by limiting free market economies, progress and inclusive wealth creation because Smith was 'optimistic about the effects of progress and, specifically, commercialism' for the flourishing of society. For Smith corruption can be viewed as systemic in terms of state regulation and laws. In many cases regulations were also influenced by wealthy and influential classes like merchants. Therefore, Smith was opposed to mercantilism and specifically its collusion with state structures. Smith ([1776] 2007:102) notes that traders were in control of the councils of towns and cities and used regulation to manipulate the market for their benefit. Regulatory corruption further creates the space for moral failure of individual public officials. This complex network of corruption ultimately erodes free market commerce and the liberty of citizens. An example is the regulation of promissory notes offered by bankers, which private citizens have to accept, sometimes to their own financial detriment (Smith [1776] 2007:252).

According to Hill (2006:639), Smith's scientific political economy should be understood in the context of widespread corruption in England that was denoted by a general 'loss of virtue in the polity (classical) exemplified and exacerbated by the widespread abuse of public office for private gain (modern)'. The broader view of corruption, focusing on loss of belief or conviction in the values of the Enlightenment, led to systemic corruption, which was combined with individual moral decline. Corrigan and Sayer (1985:89) states that as a result English politics was becoming a 'racket' operated by elite groups for their private gain and at the expense of citizens.

It is clear that individual morality was compromised, which impeded the liberty and equal rights of citizens, but this was directly linked to a decline of conviction (or faith) in the virtues of the Enlightenment - liberty and equality.

Hill (2006:647) highlights Smith's belief that systemic corruption was mainly a result of the loss of faith in natural liberty. 'Corruption consists in the violations of the system of natural liberty, including violations that corrupt the naturally self-governing behavior of individual actors'. Natural liberality is at the heart of progress and the advancement of the individual and has the potential to address the ills associated with modernism.

Therefore, corruption is not only a problem of virtue or moral failure; it is rather a problem of regulation and control that impedes the natural progress of the individual and commerce. According to Hill (2006), corruption is also associated with:

$[R]$ eligious fanaticism and sectarianism; political faction, and monolithic, paternalistic, and intrusive forms of governance, including any institutional and legal impediments to the free play of the market and the development of independent moral character. (p. 647)

This problem for Smith became acute when interference in commercial affairs started to negatively impact the livelihood of the poor, which is indicative of society's total loss of virtue or morality (e.g. the failure of the Poor Laws). In this regard, faith and morality are closely linked analytical aspects to understand and address corruption.

In what follows, Smith's views of corruption will be highlighted in terms of the corruption of moral sentiments in Smith (2005), as well as operations of the state combined with the personal moral failure that took place in the tax system, regulations like the Poor Laws and the judiciary, as presented in Smith (2007).

\section{Corruption of moral sentiments}

In TMS (2005), Smith interprets corruption in a context of moral sentiments and moral development that is influenced by sympathy and self-interest (Rathbone 2015, 2018). In this regard, moral development takes place within social engagements and assessment of behaviour that is acceptable (or evokes the sympathy of others). To adjust behaviour that is acceptable, we mentally enact possible events and attempt to assess the reaction of others. The impartial spectator is the mechanism that is evoked for the cognitive construction of possible events and assessment of these events (Rathbone 2019a). In this case, we generally assess that people sympathise with those who are suffering, and we despise those who harm the innocent.

However, sometimes the natural instincts of sympathy are disrupted. This is particularly clear in our uncritical admiration of wealth and neglect of the poor because we want to avoid suffering (Smith 2005:53).

Another example of the disruption of sympathy is the corruption of youth. Smith (2005:80) states that youth are 
found to sometimes propose unacceptable conduct, 'licentious $[y]$ ridiculing the most sacred rules of morality, and professing, sometimes from the corruption, but more frequently from the vanity of their hearts, the most abominable maxims of conduct'. It seems that according to Smith, it may at times be difficult to distinguish between corruption and vanity (self-absorbed and/or narcissistic behaviour). What is clear is that 'sacred' rules apply, and therefore convictions play a role in determining sacred rules that must be set apart and differ from general 'maxims of conduct'. However, both the aspects of conviction and morality are linked to each other and have an impact on one another. This relationship is clearly visible when Smith refers to the relationship between motives and corruptions (Smith 2005:286). It is clear that activities that are derived from motives that are not beneficial for society are deemed corrupt. In other words, the convictions related to the social contract play a role in the analysis of corruption and the morally reprehensible behaviour that may follow.

The corruption of moral sentiments, as a result of convictional and moral aspects, is problematic for Smith, and therefore he argues that justice is a crucial aspect to protect citizens from harm (Rathbone 2019b). This is not only for society but also a mechanism to avoid harm to foreign nations resulting from the limits of sympathy when there is less or no proximity. We sympathise more with people whom we know and who are close to us. Therefore, to limit xenophobia and the annihilation of nations far removed from us, it is important that a system of justice protect humanity from ourselves. According to Smith, justice and the justice system provide a structure for accountability that supplies a prerequisite for his reference to taxation, the Poor Laws and the justice system, as referred to in WN (2007).

\section{Taxation}

Smith (2007:640) states that taxes can become problematic if the only reason for them is to keep the bloated state functioning:

Every tax ought to be so contrived as both to take out and to keep out of the pockets of the people as little as possible over and above what it brings into the public treasury of the state. A tax may either take out or keep out of the pockets of the people a great deal more than it brings into the public treasury ... (p. 640)

Smith notes four ways in which this can happen: Firstly, the state may employ too many public officers whose salaries are paid from taxes collected, which does not benefit society. Secondly, the tax burden may impede business ventures because of the increase of expenses resulting from high taxes. Thirdly, the penalties associated with tax evasion are not proportionately levied and may ruin or bankrupt a business. Fourthly, a cumbersome tax system that includes frequent visits and inspections of the financial affairs of citizens is oppressive and costly.

These aspects highlighted by Smith are some of the systemic problems associated with taxes and state corruption that support party politics and extravagant military activities. Smith argues that excessive taxes place a strain on citizens that may cause moral faltering: 'The uncertainty of taxation encourages the insolence and favors the corruption of an order of men who are naturally unpopular, even where they are neither insolent nor corrupt' (Smith [1776] 2007:640). Although there was widespread individual moral decay during the time of Smith, the state increasingly neglected its duty to serve the public by continuing a programme of increased military expansion, public debt, rising taxes and a system of patronage (Brewer 1976).

Hill (2006:641) notes that the state, according to Smith, attempted to control the private spending of people and wasted the funds received through taxes. Heavy taxes encouraged the proliferation of smuggling, decreases entrepreneurial activity and increases the intrusive scrutiny of citizens by tax collectors (Hill 2006:642). Laws that were instrumental in protecting the liberty and equality of citizens were exchanged for mechanisms of exploitation that increased individual moral decay, which in turn highlighted the decline in the conviction of the importance of the Enlightenment values. This argument can also be reversed to highlight the effect of moral decay on the conviction.

\section{The church and the Poor Laws}

The Poor Laws were enacted by Elizabeth after the destruction of monasteries in England and stated that each parish was responsible for their own poor from funds that were raised by the parish for this purpose (Smith [1776] 2007:111). The strain that these laws placed on parishes led to parishes seeking loopholes to avoid the burden that the poor placed on the finances of parishes. Soon the poor who were not from a particular village were not considered for assistance. To deal with this problem, Charles II laid down criteria in terms of residency by stating that assistance must be given to someone residing in the area for more than 40 uninterrupted days.

Within this period, a complaint about a new arrival that was sanctioned by two judges could result in the person and his or her family being expelled and sent back to his or her previous parish. These developments escalated corrupt practices, because church wardens bribed judges and/or the poor to return to their previous parishes. Later, to contain the situation, a new resident had to provide notice to the parish warden of his or her arrival in a village, but many wardens were not forthcoming by registering the new arrivals. The continued corrupt practices resulted in such a sad state of affairs that it virtually became impossible to obtain a settlement (Smith [1776] 2007:112). This also constrained common labour and the commercial activities of artificers and manufacturers to obtain residency in a village or town to conduct their business (Smith [1776] 2007:111).

The Poor Laws reflected the interplay between conviction and morals. The legal imperative of the Poor Laws was embedded in the belief that all citizens should have a certain standard of living to participate in society as a function of 
freedom and liberty. However, this belief was undermined by the loopholes that parishes used to avoid their responsibility towards the poor. The law as an articulation of the moral principle of care and charity did in turn erode the belief in freedom and liberty of the poor and workers.

\section{The legal system}

The courts are another part of society where corruption may be a problem, specifically in terms of individual morality, and at the same time they represent belief in a system of justice to protect the freedom and liberty of citizens:

The whole expense of justice, too, might easily be defrayed by the fees of court; and, without exposing the administration of justice to any real hazard of corruption, the public revenue might thus be discharged from a certain, though, perhaps, but a small encumbrance. It is difficult to regulate the fees of court effectually where a person so powerful as the sovereign is to share in them, and to derive any considerable part of his revenue from them. (Smith [1776] 2007:556)

Smith ([1776] 2007) proposes that the fees of the court should be regulated and paid to a cashier. These funds could then be distributed:

$[I] \mathrm{n}$ a certain known proportions among the different judges after the process is decided, and not till it is decided, there seems to be no more danger of corruption than where such fees are prohibited altogether. (p. 556)

A further problem of corruption in the administration of justice was the use of a stamp-duty for legal proceedings. Smith ([1776] 2007) writes:

The judges indeed might, in this case, be under the temptation of multiplying unnecessarily proceedings upon every cause, in order to increase, as much as possible, the produce of such stamp duty. (p. 558)

This is similar to other European examples where corruption occurs by unnecessarily increasing the number of words, lines and pages that are written for financial gain, which Smith refers to as 'the corruption of the law of language' (Smith [1776] 2007:558).

The abuse of the legal system for personal gain by those entrusted with power is a clear moral failure and also a failure of belief in the values that underpin society because it points to a loss of equality between people and their liberty.

\section{The Book of Amos and the prophetic tradition}

In the following section it will be argued that a theological perspective on corruption is important to understand the moral failure and the decline of conviction as analytical tools. In this regard the prophetic tradition is the main focus because of its robust socio-religious and economic critique of Israelite and Judean societies (Mays 1983).
It will become clear that the Book of Amos follows a similar structural analysis of corruption with clear moral and faith dimensions as is the case with Smith. However, it goes deeper into the problem of corruption by following structures of accountability for moral rejuvenation.

La Sor (1991:304) notes that the messages of the prophets in general are applied to the historical context of the message. In other words, prophetic messages are contextual and must be understood within the socio-political situation of a particular period in history and the injustices that took place. La Sor (1991) states:

It is a message of judgment because God's people are constantly in need of correction. At the same time, it is a message of hope, for Yahweh has not broken his covenant and will complete his redemptive purpose. (p. 305)

It is therefore a message about the society in a particular historical period and place that leans towards future rejuvenation.

A main aspect of the prophetic tradition is the criticism of economic injustice (Mott \& Sider 2000; Von Rad 1968). Economic injustice is in many cases directly linked to the moral failure of societal institutions and individuals. This denouncement is based on the failure to follow the law of God, which is the basis of righteousness. Although there is no single concept that can be associated with corruption as understood today, there are similarities associated with the failure of societal structures resulting from failure to obey the law of God.

This is not only a result of individual moral failure but rather the failure of socio-religious structures as a collective, with the result that the poor and most vulnerable members of society suffer the most. Hence, those most reliant on society for assistance are neglected and even exploited by people in power. The implication is that the trust that vulnerable members of society place in others is shattered, and secondly, society becomes broken or dysfunctional. Although Jewish societies in the Old Testament, and specifically the Book of Amos, did not function like a modern state, and the forms of corruptions that occurred were different, it will be argued that in most cases two analytical principles are present, as was the case with Smith, namely conviction (faith) and morals:

- There is a core conviction or faith. In the Old Testament this is the belief in a deity, the God of Israel. Modern society is rooted in the beliefs of the Enlightenment and values of individuality, freedom and equality.

- The belief is supported by morals or norms - the Torah in the Old Testament and the laws of the state in contemporary society.

The analytical criteria that form the basis or common ground between Smith and the Book of Amos will be discussed in greater depth in the followingt section. 


\section{The Book of Amos}

La Sor (1991:302) follows a broad classification of the prophets of the Old Testament according to which the Book of Amos is part of the post-division of the monarchies of Israel and the Judah period (more or less between 800 and $675 \mathrm{BCE}$ ). During this period, prophets were advisors to the monarchy, or professional prophets ${ }^{3}$ (Am 7:12). They counselled the kings, encouraged them to follow the law of God and rebuked them for failing (La Sor 1991:303). Later the attention of these prophets turned to the people and the nation, of which Amos is an important example. In this context, Amos's response to Amaziah in 7:14 is a clear shift that introduces a new type of prophet who is not concerned with the profession as a means of income. The focus is rather on the harsh socio-economic suffering of the nation under the loss of faith and morality by those in power.

Corruption is also related to the failure of professional prophets to rebuke the king, probably out of fear of the loss of privilege and power. Therefore, Amos, a herdsman from Judah and an outsider not influenced by the corrupt practices in Israel is the most appropriate person to prophesy in the northern kingdom of Israel. Hence the clash between Amos and Amaziah in 7:10-17 is of critical importance, because it highlights the critique of corrupt leadership that swept through the northern kingdom during the time of Jerobeam ben Joash (Jerobeam III, 793-753 BCE) (La Sor 1991:320). This was a time of increased territorial advancement in the kingdom, which inspired national and religious pride. The problem highlighted by La Sor (1991:321) is that the wealth associated with territorial advancement 'brought injustice and greed; the poor were neglected, then persecuted' and religion became 'formalistic', with the rich dominating. La Sor (1991:321) notes that corruption was based on the class distinction between rich and poor, based on Amos 5:10f., $15 ; 16: 4$.

However, this view on the corruption that took place does highlight the systemic nature of corruption, because it is also mentioned in 5:4f. that the judiciary and the temple (3:14, 5:21-24) were compromised. The basis of the systemic corruption was the fact that Yahweh was not worshiped, and the law was ignored - conviction and morality declined. This represents a clear disregard for the covenant, which is the basis for social coherence and prosperity. In other words, the systems that maintained order through following the law became corrupt.

La Sor (1991:323) states that scholars like Wellhausen and Whitley argued that Amos introduced a form of ethical monotheism - 'the concept that there was only one God, who demanded ethical behavior'. This is highlighted by the numerous references to the covenant and the use of the covenant name 'Yahweh' (La Sor 1991:324). The focus on justice is therefore directly linked to the ancient covenant laws, which apply to individual and national destiny.
Therefore, it is clear that faith in God was replaced by wealth, and with it resulted in the decline of morality.

\section{Corruption and the Book of Amos}

The article by Ruth Alvarado (2017) entitled 'Facing Corruption Today in the Light of the First Testament' (Am 8:1-7) that appeared in the Journal of Latin American Theology: Christian Reflections from the Latino South (2017), after the Lima conference on corruption with the theme Corruption Kills (2016), highlights the devastating consequences of corruption in South America and Peru specifically. Alvarado (2017:41) states: 'Hear this word, proclaim to the fortresses, testify against the corrupt governments, unmask the hypocrites in government and in religious service, do not stop speaking denounce, the exploiters'. Alvarado (2017:41) highlights that the problem of corruption can be traced to the powerful, their loss of conviction in the values that underpin their office and their moral decline. Alvarado does not reduce his criticism of corruption to a general rejection of capitalism and greed. To support this perspective, Friedman and William (2011:1018) argue that for Amos, 'acquiring wealth is acceptable' is not a sign of moral failure or lack of faith in God. However, using it for display and the 'desire for a flamboyant lifestyle' at the expense of the destitute is unacceptable (Friedman \& William 2011:1018).

The role of conviction (faith) and morality in the Book of Amos will be discussed in terms of a close reading of two important text references that highlight corruption in Judah and Israel, namely judgement over Judah (2:4-5) and judgement over Israel (2:6-8).

\section{Judgement over Judah (Am 2:4-5)}

The main judgement in the text refers to the failure to

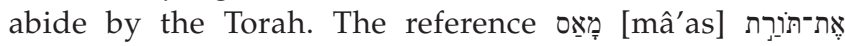
['êth-tôrâh] in Amos 2:4 means 'to spurn or have a disdain for the law of God'. Instead of following the truth of the law of God, Judah turned to כָָָ [kâzâb; lies, deceit and

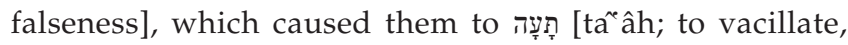
waver or hesitate], deceive, stray from or corrupt the way of their fathers.

According to this verse, Judah as a nation has betrayed the core values articulated in the law of God. The result is total decay, which set in because the truth of the law no longer directed the governance of the nation. Truth was replaced by lies and falsehoods that betrayed the example of faithfulness of their fathers. Following the law of God is the basis of their faith that was ultimately betrayed - loss of conviction. Without their faith and their corresponding moral walk, society becomes dysfunctional and corrupt. In this regard, corruption is something that takes hold of a society when laws as a function of the value system have no more relevance or are discarded or not applied. The possible effect of this is that there is no shared value system that is the basis for order and the functioning of society. Such a 
chaotic state of affairs may result in rampant egoism to secure personal security and power. All that remain are deceit, mistrust and tension, which destroy society.

Failure to function within the parameters of morality endangers society and ultimately results in the suffering of the most vulnerable. This leads to the breakdown of trust and perpetuates the brokenness of society. In the Old Testament the brokenness of society is commonly linked to the failure of the monarchy. Today it is linked to the failure of the state. However, those in power will be held accountable for their deeds, and the wealth that people accumulated through injustice will be destroyed (Am 2:5).

\section{Judgement over Israel (Am 2:6-8)}

The judgment over Israel is a more specific reference to the economic scandals that took place. Amos (2:6) states that the people of Israel must be held accountable for their

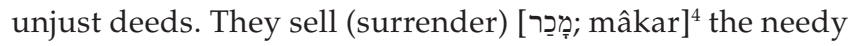

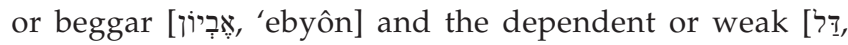
dal] for profit. Dearman (1988:20) refers to this practice as 'debt slavery' - the practice of selling the debtor ${ }^{5}$ into slavery to cover his or her debt from a creditor. ${ }^{6}$ In the verse, the character of those who are sold are highlighted as the צַדִיק [tsaddiyq; the righteous or lawful]. Thomas (2003:185) notes that many small-scale farmers were reliant on loans because of crop failures. As security the land, their children and ultimately they themselves were offered for the debt accrued and could therefore be sold as slaves. Therefore, those who are viewed as necessary for personal gain are relinquished for פֶֶּ [keseph; silver, money or for a price].

The personal gain of the powerful is the main focus, and it has direct consequences for the rest of society. The problem is that there are no righteous people to provide guidance or moral leadership for society. Society is consumed by the loss of faith and moral decay. Not only are the righteous exchanged for personal gain, the rottenness of society is emphasised by the lack of empathy for the most vulnerable members of society. The [ִירוֹן ['ebyôn] that means 'sense of want, destitute, poor, beggars or the needy' are sold for [na'al; sandal or shoes]. This verse notes that the corruption of those in power who have the ability to decide the lives of others are motivated by personal gain, which destroys the moral fabric of society - by selling the just for profit. They sell the indebted and poor for personal gain without considering their responsibility to take care for them. Not only do they not fulfil their divinely sanctioned responsibility to take care of the poor, they increase the suffering of the indebted by probably selling them into slavery for self-enrichment and narcissism (Am 2:6).

4.The word ọָ [mâkar] is usually associated with arranged marriages of daughters, selling someone or slavery.

5.An entity or individual that has a financial obligation to a creditor.

6.An entity or individual that must accrue obligations from debtors.

\section{The Book of Amos, Adam Smith and accountability}

In general, the focus of the pre-exilic prophetic tradition was on the weakness of the monarchy's ability to abide by the theocratic principles of rule. The principles of theocratic rule were contained in the Torah, which generally focused on religious piety and social responsibility. Although these two views of corruption are historically distinct, and comparison may end in dangerous generalisations, there is a matter of principle that does overlap.

The first is the failure and/or weakness of structures and processes resulting from a decline in conviction (faith); and secondly, the negative impact this has on the most vulnerable people in society (morality). 'Vulnerable' does not at any point imply that some people do not have the capability to rise above their circumstances; it is not a value judgement. Rather, it notes that because of systemic corruption, some people are more exposed to the impact of moral deficiency.

A similar relationship between conviction (faith) and morality is present in the work of Adam Smith in terms of his references to corruption. Discussions by Smith about corrupt practices associated with the corruption of moral sentiments, taxation, the Poor Laws and the legal system highlight that belief in the liberty and equality of citizens is undermined by the moral failure of individuals; at the same time, individual moral failure in terms of failure to comply with moral principles or attempting to circumvent the law (or misusing positions of power for personal gain) is a direct challenge to the belief system in which the morals are embedded. From the perspective of classic economics, it is clear that corruption is rejected as the failure of conviction and morals that are crucial for the flourishing of society. However, what is clear from Smith's discussion of corruption is that the restoration of convictions is crucial for society to function optimally.

This process of restoration is directly linked to morality and becomes visible in the day-to-day behaviour of the citizens and people in power.

For Smith, 'corruption' refers to weakness in an organisation or process that creates an environment for individuals to act corruptly. The latter can be associated with moral failure in which an agent or a person who holds a public office fails to act in accordance with his or her public responsibilities through moral failure.

Conversely, the Book of Amos (2:6) highlights that people are accountable to God for their failure of conviction and morality. This is an important aspect in dealing with corruption, because there are consequences.

Although there may be a loss of conviction and morality, there are also structures of accountability that will be initiated for judgement and restitution. This is crucial for sustainable societal development as a function of healing and rejuvenation (Venter \& De Regnaucourt 2010). 
For Smith (2005), accountability is a salient aspect of the functioning of society. The justice system is crucial as the system of accountability (Rathbone 2019b). Reference to the weakness of structures focusses on the processes of a system that lacks mechanisms of accountability and consequences for defiant behaviour. At its core, this situation undermines the morals of a society; at the same time, it is reflective of a society that has lost conviction in the principles of liberty and equality. It is a matter of faith and/or the loss of faith and the values that faith is based on. Therefore, the one is an extension of the other - faith in values will result in an effort to support them, whereas the presence of values in society would indicate belief in their relevance. These values are enshrouded in the Constitution of the Republic of South Africa (1996), which underlines the responsibilities of the state and citizens and proposes structures of accountability for both. Informally, social media and public opinion through various platforms highlight the importance of transparency and accountability.

In a multireligious society like South Africa, the singular presentation of a religion cannot be the basis for change. Rather, inter-religious dialogue is required to find common ground. Therefore, the Constitution of the Republic of South Africa (1996) and institutions like the constitutional court provide important common values and institutions of accountability. This can serve as common ground because the principles of the Constitution of the Republic of South Africa (1996), such as human rights, dignity, respect for life and nondiscriminatory practices, are mostly shared by all religions.

From the aforementioned points, it is clear that any references to the Book of Amos as criticism of corruption and its link to capitalism have to take note of the analytical criteria of conviction and morality, which is similar to the analysis of Adam Smith. Further, both Smith and Amos highlight structures of accountability. For Smith, this meant that justice was a crucial limitation on the instinct of self-interest, so as to avoid excessive and apathetic behaviour that may do damage to others. On the other hand, for Amos God demands accountability. This aspect points to the spiritual dimension of a person and requires change of conviction and behaviour.

\section{Conclusion}

In this article, the general criticism of capitalism as a corrupt economic system by referring to the prophetic tradition and specifically the Book of Amos was challenged. This was done by comparing references to corruption in the work of Adam Smith and the Book of Amos. The analysis of Smith's work highlighted themes like the corruption of moral sentiments in TMS (2005) and taxation, the Poor Laws and the church and the legal system in WN (2007). The discussion of the Book of Amos focused on the prophet's criticism of Judean and Israelite societies, the monarchy and religious institutions. The comparison revealed that both Amos and Smith used conviction and morality as dimensions to analyse corruption.

Consequently, it was argued that these dimensions are important to analyse and address corruption in the
South African context and the development of structures of accountability. It is also important to provide a critique of capitalism that is nuanced and informed to create the space for authentic dialogue between theology and economics. In this regard, generalised criticism of capitalism places barriers on dialogue and limits possible fruitful discussion to explore creative and sustainable solutions to socio-economic problems like corruption.

\section{Acknowledgements Competing interests}

The author has declared that no competing interests exist.

\section{Author's contributions}

M.R. was the sole author of this article.

\section{Ethical consideration}

The Economic and Management Sciences Research Ethics Committee of the North-West University reviewed the research and concluded that this is a no-risk study (NWU00711-20-A4).

\section{Funding information}

This research received no specific grant from any funding agency in the public, commercial or not-for-profit sectors.

\section{Data availability statement}

Data sharing is not applicable to this article as no new data were created or analysed in this study.

\section{Disclaimer}

The views and opinions expressed in this article are those of the author and do not necessarily reflect the official policy or position of any affiliated agency of the author.

\section{References}

Alvarado, R.Y., 2017, Journal of Latin American Theology: Christian reflections from the Latino South, edited by L. Scott, Fraternidad Teologica Latino-americana, Eugene, OR.

Brewer, J., 1976, Party, ideology and popular politics at the Accession of George III. Cambridge University Press, Cambridge.

Carroll R, M.D., 2002, Amos - The prophet and his oracles: Research on the Book of Amos, Westminster John Knox Press, London.

Corrigan, P. \& Sayer, D., 1985, The great arch: English state formation as cultural revolution, Basil Blackwell, Oxford.

Dearman, J.A., 1988, Property rights in the Eighth century prophets: The conflict and Its background, SBLDS 106, Scholars Press, Atlanta, GA.

Friedman, H.H. \& Adler, W.D., 2011, 'Moral capitalism: A biblical', American Journal of Economics and Sociology 70(4), 1014-1028. https://doi.org/10.1111/j.15367150.2011.00800.x

Haymond, J.E., 2016, Biblical critique of crony capitalism, Business Administration Faculty Presentations, 66, viewed 21 April 2020, from http://digitalcommons. cedarville.edu/business_administration_presentations/66.

Hill, L., 2006, 'Adam Smith and the theme of corruption', The Review of Politics 68(4), 636-662. https://doi.org/10.1017/S0034670506000210

Hofstater, S., 2018, 'Counting the cost of state capture', Financial Mail, 06 September 2018, viewed 05 December 2018, from www.businesslive.co.za/fm/features/ 2018-09-06-counting-the-cost-of-state-capture/. 
La Sor, W.S., 1991, Old Testament Survey: The message, form, and background of the Old Testament, William B. Eerdmans, Grand Rapids, MI.

Lewis, J., 2011, 'Corruption: The hidden perpetrator of under-development and vulnerability to natural hazards and disasters', JAMBA: Journal of Disaster Risk Studies 3(2), 464-475. https://doi.org/10.4102/jamba.v3i2.43

Mays, J.L., 1983, 'Justice: Perspectives from the prophetic tradition', Union Seminary Review 37(1), 5-17. https://doi.org/10.1177/002096438303700102

Mott, S. \& Sider, R.J., 2000, 'Economic justice: A biblical paradigm', Transformation 17(2), 50-63. https://doi.org/10.1177/026537880001700202

Rathbone, M., 2015, 'Love, money and madness: Money in the economic philosophies of Adam Smith and Jean-Jacques Rousseau', Southern African Journal of Philosophy 34(3), 379-389. https://doi.org/10.1080/02580136.2015. 1087614

Rathbone, M., 2018, 'Adam Smith, the impartial spectator and embodiment: Towards an economics of accountability and dialogue', Religions 9(4), 118. https://doi. org/10.3390/rel9040118

Rathbone, M., 2019a, 'Desire, self-love and sympathy: The irony of discovering Adam Smith in post-capitalism economics', Southern African Journal of Philosophy 38(1), 96-107. https://doi.org/10.1080/02580136.2019.1581426

Rathbone, M., 2019b, 'Self-interest, wealth and the Book of Proverbs in the South African context: Towards a Smithian alternative', HTS Journal 75(3), a5123. https://doi.org/10.4102/hts.v75i3.5123
Saviour, T.V., 2012, 'Socio-critical Sayings of Amos: A contextualized interpretation focusing on implications for theological social ethics', Inaugural dissertation for degree of Doctor Theologia, Katholisch-Theologischen Fakultät der LudwigMaximilians-Universität München.

Shuma, P., 2018, Corruption cost's SA's GDP R27 billion annually, viewed 05 December 2018, from www.sabcnews.com/sabcnews/corruption-costs-sas-gdp-r27-billionannually.

Smith, A., [1759] 2005, The theory of moral sentiments. Sixth edition. MetaLibri, Obra etitada e publicada SaoPaula, Brasil.

Smith, A., [1776] 2007, An inquiry into the nature and causes of the wealth of nations, Digital Copy: Metalibre, Sao Paula, Brasil.

Thomas, P.P., 2003, Jeroboam II the King and Amos the Prophet: A social-scientific study on the Israelite Society during the 8th Century BC, ISPCK, Delhi.

Umeanolue, I.L., 2018, 'Critique against Social Injustice in the Book of Amos: Its relevance to development in Nigeria', UJAH 19(2), 182. https://doi.org/10.4314/ujah.v19i2.10

Venter, D. \& De Regnaucourt, E., 2010, 'Corruption: An Octopus that strangles all it touches', Professional Accountant 2012(1), 26-27.

Von Rad, G., 1968, The message of the prophets, S.C.M. Press, London.

Wallis, J.J., 2004, The concept of systematic corruption in American political and economic history, in Corruption and Reform: Lessons from America's Economic History, pp. 23-62, Edward L. Glaeser and Claudia Goldin, editors, University of Chicago Press, Chicago. 